\title{
EVOLUTION OF THE OBSCURA GROUP DROSOPHILA SPECIES. I. SALIVARY CHROMOSOMES AND QUANTITATIVE CHARACTERS IN D. SUBOBSCURA AND TWO CLOSELY RELATED SPECIES*
}

\author{
C. B. KRIMBAS AND M. LOUKAS \\ Department of Genetics, Agricultural College of Athens, Greece.
}

Received 9.x.83

\section{SUMMARY}

\begin{abstract}
Three closely related Drosophila species of the "obscura" group have been examined: Dropophila madeirensis, D. guanche and D. subobscura. Some crosses are possible between them and $F_{1}$ progeny were used in order to clarify chromosomal homologies. $D$. madeirensis has the following constitution in relation to $D$. subobscura: $A_{m+1} ; J_{S T} ; E_{S T} ; O_{3} ; U_{1+2}$ while $D$. guanche has: $A_{m+g} ; J_{g} ; E_{g}$; $O_{3+\mathrm{g}} ; U_{1+2}$ (where $m$ and $g$ indicate inversions specific to those species). Some data are also presented on the inheritance of eight different quantitative characters used by some taxonomists to differentiate other palearctic obscura group species.
\end{abstract}

\section{INTRODUCTION}

Several species belonging to the "obscura" group of the genus Drosophila have been extensively used in population genetic and speciation studies. Thus the American species $D$. pseudoobscura and $D$. persimilis were the favourite material of Th. Dobzhansky and his school while the palearctic $D$. subobscura was used by the European workers. Several other American species of the affinis sub-group were also studied. The information, however, concerning the evolution of all the 32 species belonging to this group and known until now, is sparse and consists mainly of the construction of phylogenetic trees based on electrophoretic data. We intend in this series of papers to present more data on the evolution of obscura group species and especially of the palearctic ones. The present paper deals with the chromosomal homologies between $D$. subobscura, $D$. guanche and $D$. madeirensis: homologies have been traced mainly by synaptic relations observed in $F_{1}$ hybrids. Some indications are also provided concerning the inheritance of eight quantitative characters that taxonomists use in order to distinguish obscura group species.

\section{Materials}

A strain of Drosophila guanche Monclús (1976) and a strain of $D$. madeirensis Monclús, kindly provided by Professor Antonio Prevosti, were used in this study. D. guanche originated from the Canary Islands where it is confined and $D$. madeirensis is native to the island of Madeira.

* This paper is dedicated to Professor Ernst Mayr for his 80th birthday. Besides being a leading evolutionist and one of the founders of the synthetic theory, he also propounded and

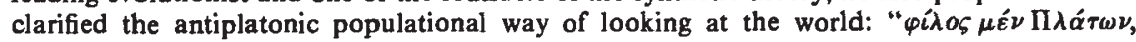
$\varphi \iota \lambda \tau \dot{\tau} \tau \eta \delta \dot{\varepsilon} \eta \alpha \lambda \dot{\eta} \vartheta \varepsilon \iota \alpha "$. 
Three strains from $D$. subobscura were used in this study: the Kusnacht strain monomorphic for the Standard gene arrangements in all its chromosomes $\left(A_{S T}, E_{S T}, J_{S T}, O_{S T}, U_{S T}\right)$, the $c h c u$ strain (a strain homozygous for the cherry eyes and curled wings recessive mutations and for the gene arrangements $A_{S T}, E_{S T}, J_{S T}, O_{3+4}$ and $U_{S T}$ ) and finally the strain No. 8 from Crete having the following gene arrangements: $A_{2}, E_{S T}, J_{S T}, O_{3+4}, U_{1+2}$.

All measurements of lengths, teeth, chaetae were performed under microscopic observation of preparations of the respective parts of the fly mounted in euparal.

\section{SPECIES CROSSES AND HYBRIDS}

Crosses in all directions cannot be performed. Only two successful crosses yield adult progeny and are the following:

(i) $+D$. madeirensis $\times{ }^{\star} D$. guanche. This yields a small number of $F_{1}$ female and male flies both of which are sterile. Thus an $F_{2}$ and backcrosses to parents cannot be obtained.

(ii) $\& D$. madeirensis $\times ð D$. subobscura. The $F_{1}$ males are sterile, but $F_{1}$ females are fertile and can backcross to both parents. These two crosses were obtained relatively easily when the strains of $D$. guanche and $D$. madeirensis first arrived in our laboratory. It proved, however, more difficult to repeat them some months later on.

\section{THE Mitotic CHROMOSOMES}

It is well known that Drosophila subobscura displays twelve chromosomes in complete somatic mitosis: two dots and five pairs of rods in females. One of these pairs consists of the sex chromosomes.

Squashes from larval nervous ganglia of $D$. guanche have also revealed twelve chromosomes; two dots and five pairs of rod-like chromosomes (chromosomes of one or two pairs could bear a small, heterochromatic? second arm). Some individuals display an unequal pair while others do not. The unequal pair are apparently the sex chromosomes, the Y being a smaller, nearly dot-like, chromosome.

Dots are rather small and could be easily missed. They are not seen in similar microscopic preparations of $D$. madeirensis, but this is not a final proof of their absence. Ten chromosomes, forming three pairs of rods and two pairs of bigger rod-like or perhaps slightly acrocentric chromosomes with a smaller (heterochromatic?) arm are seen clearly.

Thus there is a good correspondence between the mitotic chromosomes of these three closely related species.

\section{SAlivary GLAND CHROMOSOME HOMOLOGIES BETWEEN D. MADEIRENSIS AND D. SUBOBSCURA}

The $A(=X)$ chromosome of the $F_{1}$ female hybrids between $D$. madeirensis and $D$. subobscura, when a $S T$ gene arrangement strain of this last species is used in the cross, shows two distantly located inversions (plate 1a). The first is a small one, located at the distal end of this chromosome (the free end) and involves the terminal section $16 \mathrm{BCD}$, which is 


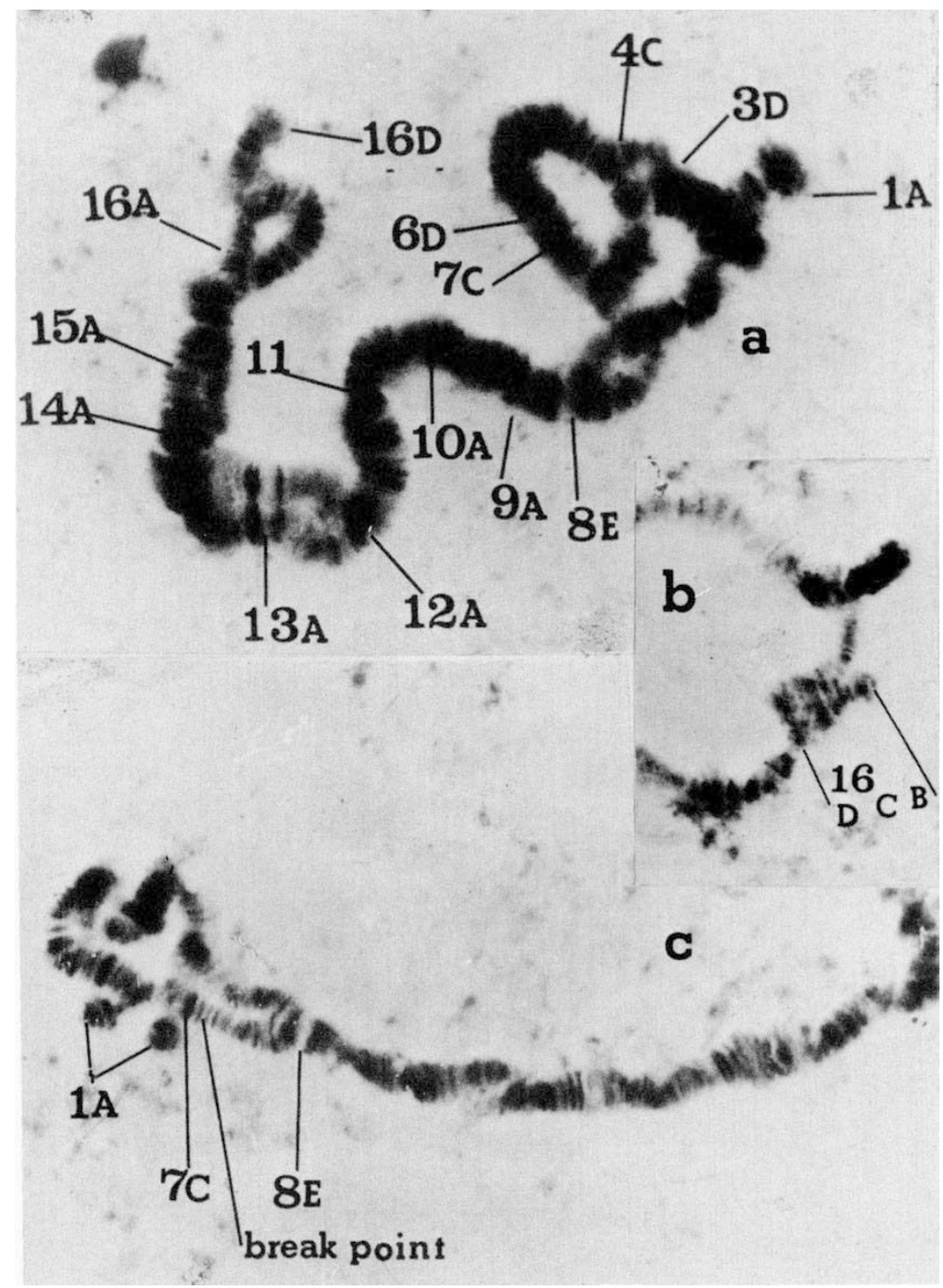

Plate 1. The $A(=X)$ chromosome in female $\mathrm{F}_{1}$ hybrids from the cross $D$. madeirensis $\times$ D. subobscura. 
inverted in $D$. madeirensis. It is the only specific inversion of $D$. madeirensis found in this material and it seems that our strain of $D$. madeirensis is monomorphic for it. The synapsis in an inversion heterozygote, an $F_{1}$ hybrid, is clearly seen in plate $\mathrm{lb}$, where after synapsis the two homologous chromosomes depart unpaired to the left, thus permitting a perfect match of their distal ends. The second inversion is a longer one located near the proximal end of the chromosome, the end near to the centromere. Plate lc shows clearly the distal break point located near $7 \mathrm{C}$. We feel that it is an identical inversion to $A_{1}$, one found in several natural populations of $D$. subobscura and for which our $D$. madeirensis strain seems to be monomorphic. A final proof of the identity will be provided when $D$. madeirensis will be crossed to an $A_{1}$ strain of $D$. subobscura.

The $E$ chromosome of $D$. madeirensis in our strain shows a perfect synapsis with the $E_{S T}$ of $D$. subobscura along nearly all its length (plate $2 a$ ). After the section 57 (which is the usual landmark for $E$ ) and towards the centromere end (at the beginning of 54), the homologous chromosomes systematically do not synapse although the banding pattern is more or less similar: the asynapsis is probably due to minor differences. In the same figure a complete synapsis can be observed in the dot (section 100).

A perfect synapsis is also observed in most parts of the $J$ chromosome from section 34 to section 20 inclusive, in the $F_{1}$ hybrids when the subobscura chromosome is of the $S T$ gene arrangement (plate $2 \mathrm{~b}$ ). The free end (section 35) shows a partial asynapsis, perhaps due to minor differences, but the banding pattern seems similar. In the same figure the dot and the proximal part of the $E$ chromosome are also shown. In plate $5 \mathrm{~b}$ the synapsis of the sections 19 to 17 of the $J$ chromosome (part near the centromere) is nearly perfect. A simple inversion is seen near the distal end of chromosome $O$ in $F_{1}$ hybrids when the subobscura parent strain is monomorphic for the $\mathrm{O}_{3+4}$ gene arrangement (plates $3 \mathrm{a}$ and 4 ), while another simple inversion, but further from the distal end, is observed when the subobscura parent has the $O_{S T}$ gene arrangement (plate $3 \mathrm{~b}$ ). It is quite evident that our $D$. madeirensis strain has an $\mathrm{O}_{3}$ inversion in its $O$ chromosome. This is the hypothetical missing link between the $O_{S T}$ gene arrangement and that produced by the two overlapping inversions $O_{3+4}$. It was not found until now in any of the nearly hundred natural populations of $D$. subobscura studied (Krimbas and Loukas 1980 for a review, and Sperlich et al., 1981, Larruga et al., 1983, de Frutos pers. com. for more recent data not included in this review) and was supposed to have been eliminated according to the triad rule formulated by Bruce Wallace (1953). It has been, however, preserved in $D$. madeirensis (and in $D$. guanche, as will be mentioned below). In plates $3 \mathrm{a}, 4$ and $3 \mathrm{~b}$ the landmarks are also indicated corresponding to those of the map of Kunze Mühl and Müller (1958). In plates 3a and 4 the combination shown is $\mathrm{O}_{3} / \mathrm{O}_{3+4}$ which displays the simple inversion loop $\mathrm{O}_{4}$ on a homozygous $\mathrm{O}_{3}$ background, while in plate $3 \mathrm{~b}$ the combination shown is $\mathrm{O}_{3} / \mathrm{O}_{S T}$ which displays the simple inversion loop $\mathrm{O}_{3}$ on a homozygous $O_{S T}$ background. Apart from that, the $O$ chromosomes of the two species seem to pair nearly perfectly-there are some small banding differences, such as bands missing etc., in the sections 89,87 , perhaps $83,79,78$ and especially in 76 and 75 . Plate $5 \mathrm{~b}$, at the right, shows a $\mathrm{O}_{3} / \mathrm{O}_{3+4}$ inversion and partial asynapsis near the centromere end of the $O$ chromosome. 
The combination of the $U$ chromosome of $D$. madeirensis in our strain with a $U_{S T}$ of $D$. subobscura shows the two characteristic and contiguous (but not overlapping) inversions $U_{1+2}$ (plates 6a and 6b). That the $U$ chromosome of $D$. madeirensis from our strain has the gene arrangement $U_{1+2}$ is proved in plate $5 \mathrm{a}$, which displays the chromosomes of the $\mathrm{F}_{1}$ hybrid between $D$. madeirensis and strain No. 8 of $D$. subobscura, a strain monomorphic for the $U_{1+2}$ gene arrangement. There are no inversions and there is a perfect synapsis from section 53 towards the other chromosome end. This is shown in the middle of the figure. At the left of the same figure we can observe the perfect synapsis of the $E$ chromosome, while running horizontally we can see the proximal end of the $O$ chromosome (with the characteristic asynapsis in sections 76 and 75 ) as well as the proximal end of the $J$, which in this figure is completely asynaptic with one of the two chromosomes broken at section 20. Finally, at the upper part of this photograph and also repeated at the right upper corner, the $A$ chromosome is seen with the small distal inversion together with the two simple inversions $A_{2}$ and $A_{1}$ (strain No. 8 is monomorphic for the $A_{2}$ gene arrangement).

In conclusion, our strain of $D$. madeirensis has, except for the small distal inversion on chromosome $A$ and some minor differences in other chromosomes, the following constitution of gene arrangements with respect to $D$. subobscura:

$$
A_{1}, E_{S T}, J_{S T}, O_{3}, U_{1+2}
$$

\section{Salivary gland CHROMOSOME homologies BetWeEN D. MADEIRENSIS AND D. GUANCHE}

General views of the salivary gland chromosomes of $D$. guanche are shown in plates 7 and 8 . In these figures we indicate also an interpretation of the chromosomal sections in relation to those of $D$. subobscura. Thus plate 7 shows in its upper part the distal part of the $J$ chromosome, below it the entire $O$ chromosome, which has a gene arrangement $O_{3}$ with a superimposed (overlapping) inversion specific to $D$. guanche covering the sections 85 to $91 A B$ plus $94 E$. Below that, in the middle, the chromosome $A$ is seen which retains the small distal inversion of $D$. madeirensis, namely the one involving the section $16 B C D$, and also is monomorphic for an inversion specific to this species including the sections 9 to 14 , and also does not have the inversion $A_{1}$ of $D$. madeirensis but instead bears the $S T$ gene arrangement. Below these the chromosomes $E$ and $U$ are shown. $E$ has the $S T$ gene arrangement with a specific inversion of this species including the section $71 A B$ to 73 . On the other hand, $U$ has the $U_{1+2}$ gene arrangement. The dot is shown at the left between the centromere ends of $E$ and $U$ chromosomes. The same is shown in plate 8 but here we can also observe completely the $J$ chromosome which bears the $S T$ gene arrangement with an inversion specific to $D$. guanche involving the sections $34 A$ to 31 .

The $U$ chromosome of $F_{1}$ hybrids between $D$. madeirensis and $D$. guanche is shown in plate $9 \mathrm{~b}$. Although the pairing is not perfect the homologies are clear: guanche has a $U$ chromosome of the $1+2$ gene arrangement. Plate $9 \mathrm{c}$ shows the incomplete pairing of the same $F_{1}$ hybrids for the $J$ chromosome. The inversion specific to guanche is also clearly depicted. Plate 9 a shows the pairing of the $E$ chromosome in the $F_{1}$ hybrids. 


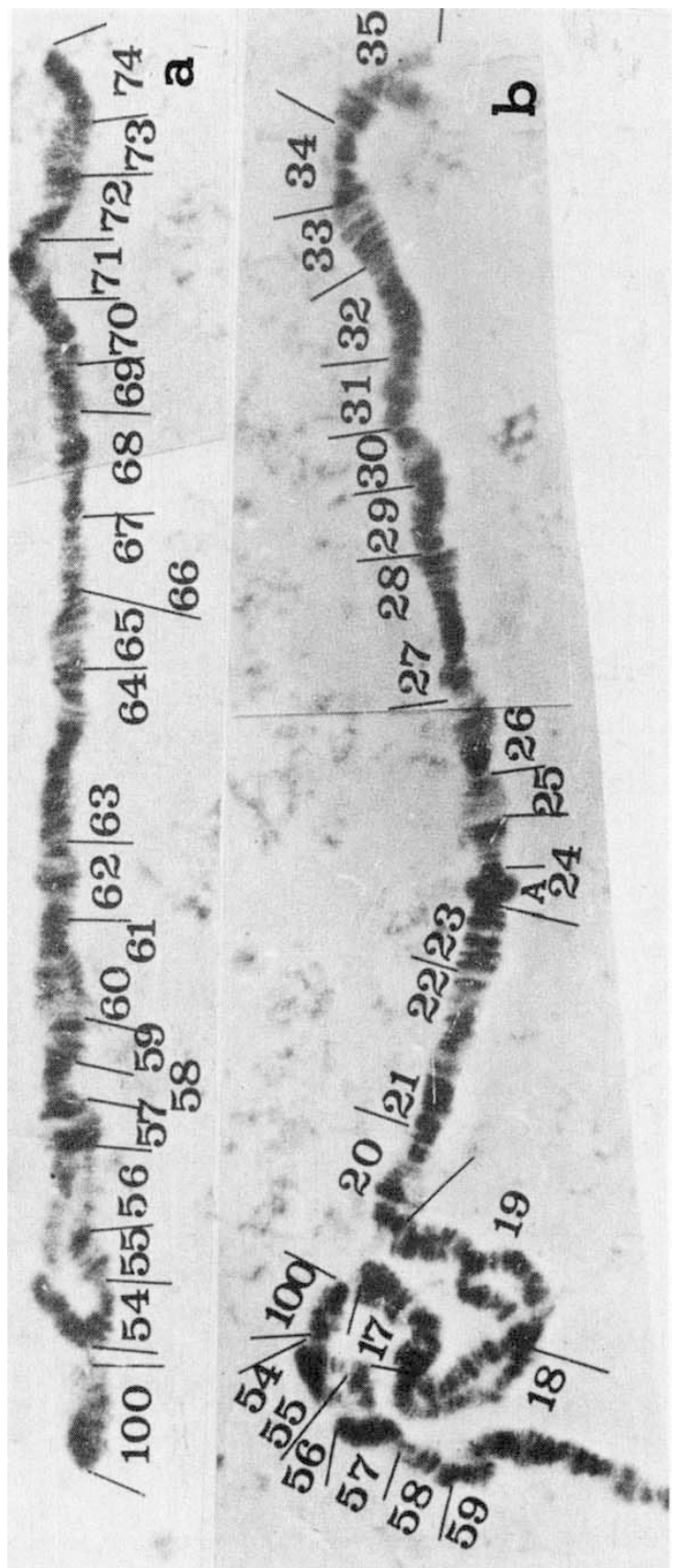

Plate 2. The $E(2 \mathrm{a})$ and $J(2 \mathrm{~b})$ chromosomes in $D$. madeirensis $\times D$. subobscura $\mathrm{F}_{1}$ hybrids. 


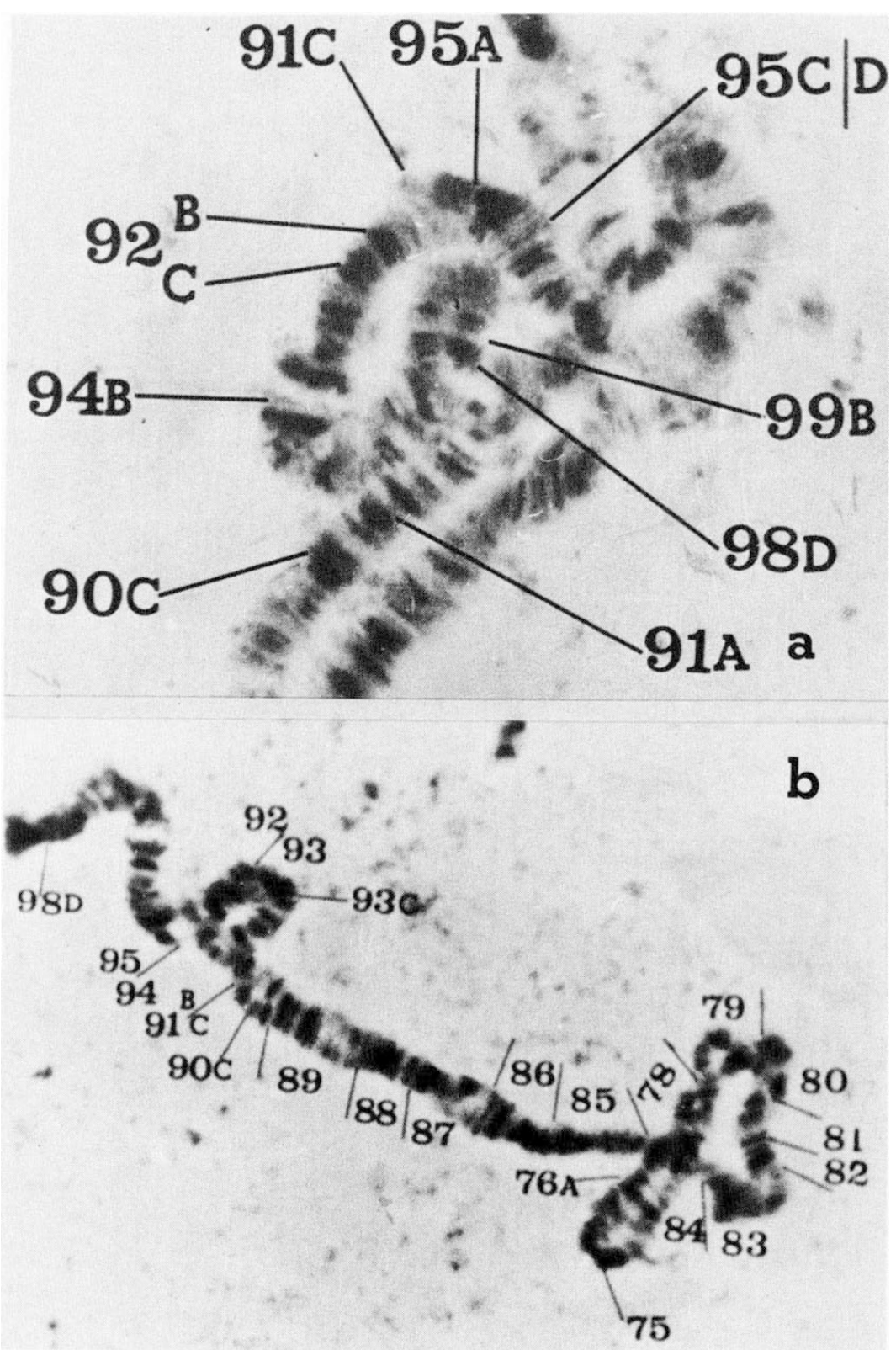

Plate 3. The $O$ chromosome in $D$. madeirensis $\times D$. subobscura $F_{1}$ hybrids. In 3 a, the $D$. subobscura parent was homozygous for the gene arrangement $O_{3+4}$, where in $3 \mathrm{~b}$ it was homozygous for $O_{\mathrm{sT}}$. 


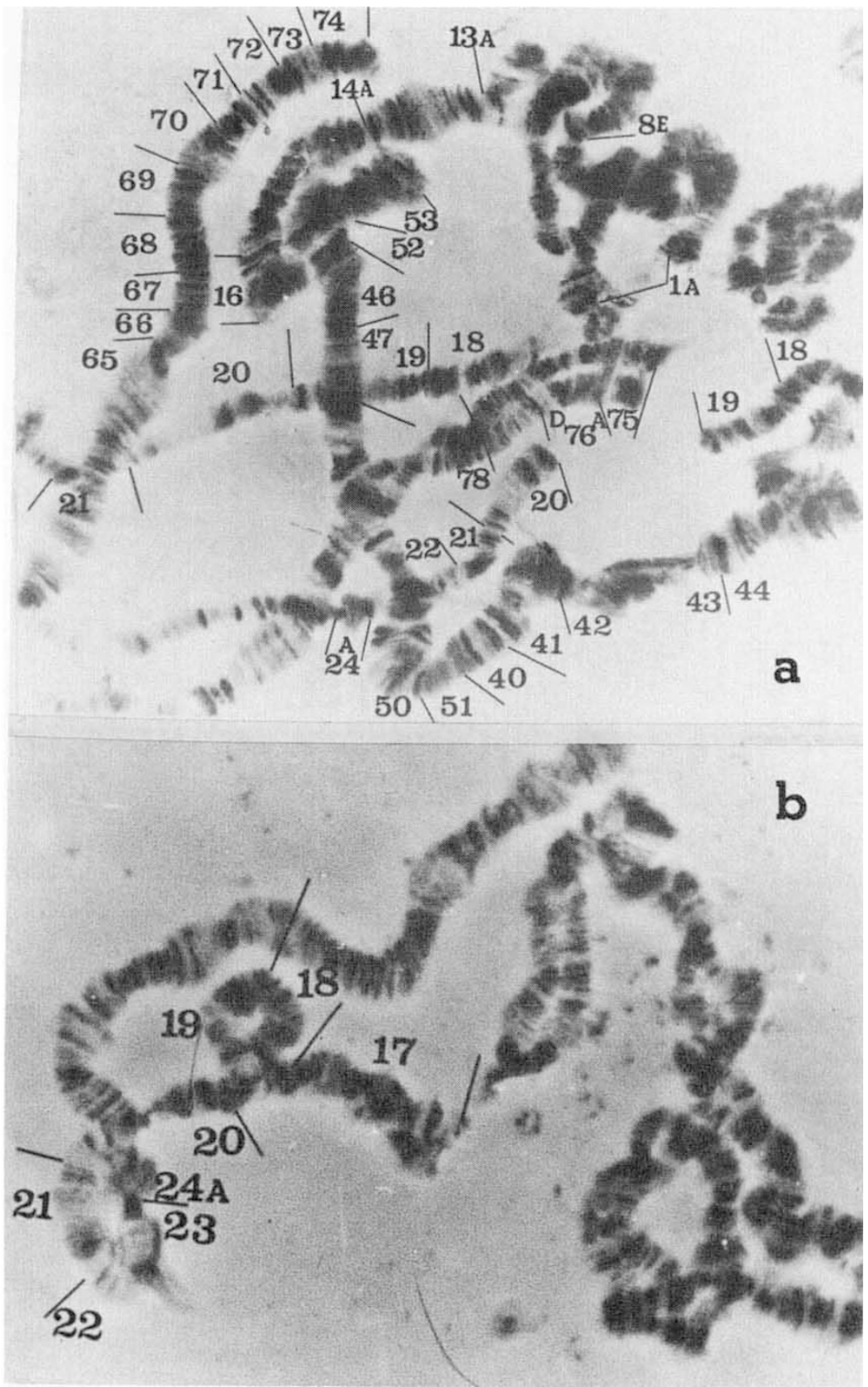

Plate 5. Chromosomes of $D$. madeirensis $\times D$. subobscura $F_{1}$ hybrids. Further explanation in text. 


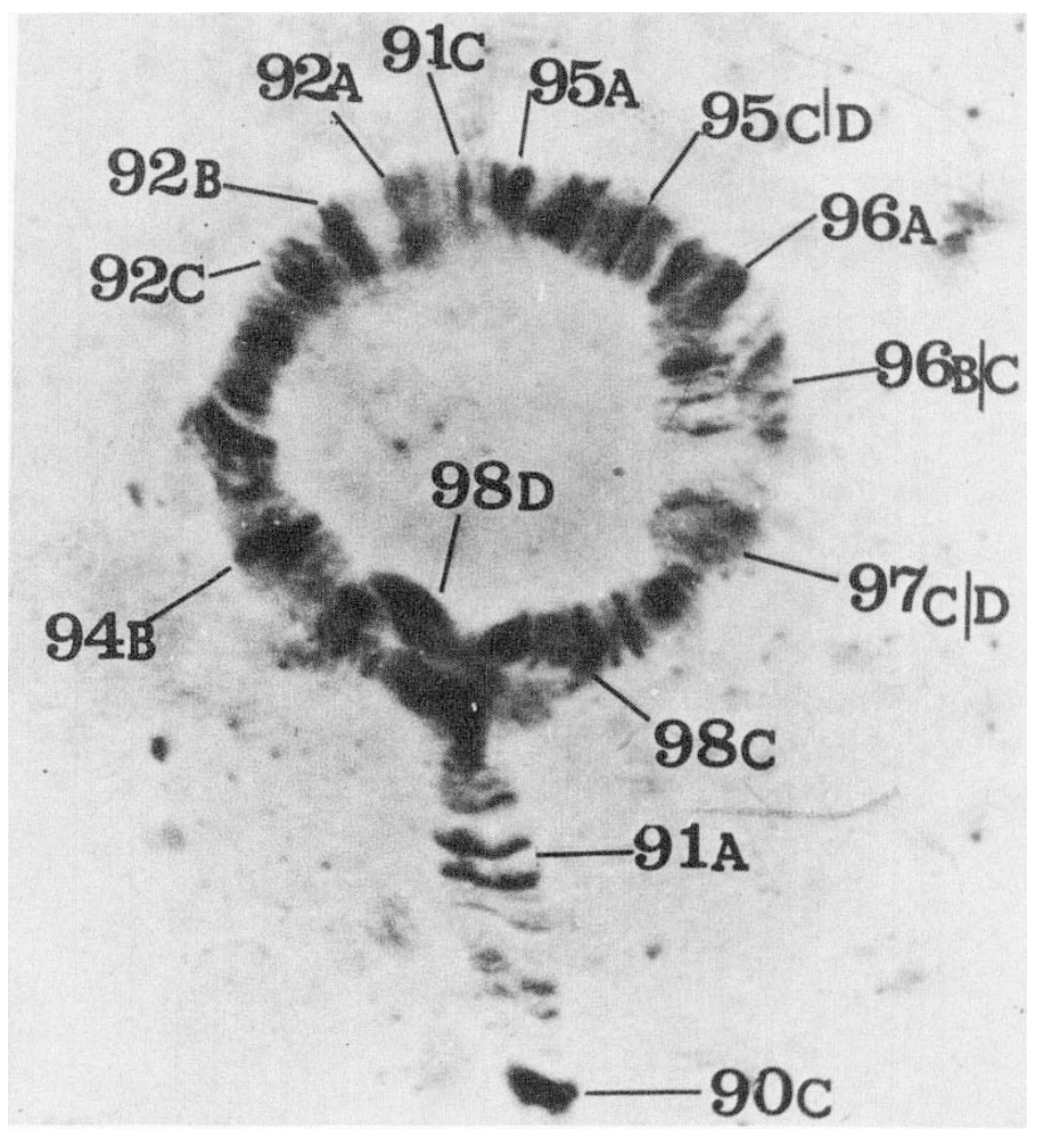

Plate 4. The terminal end of the $O$ chromosome in a $D$. madeirensis $\times D$. subobscura $F_{1}$ hybrid, where the $D$. subobscura parent was homozygous for the $O_{3+4}$ gene arrangement. The inversion $\mathrm{O}_{4}$ is shown. 


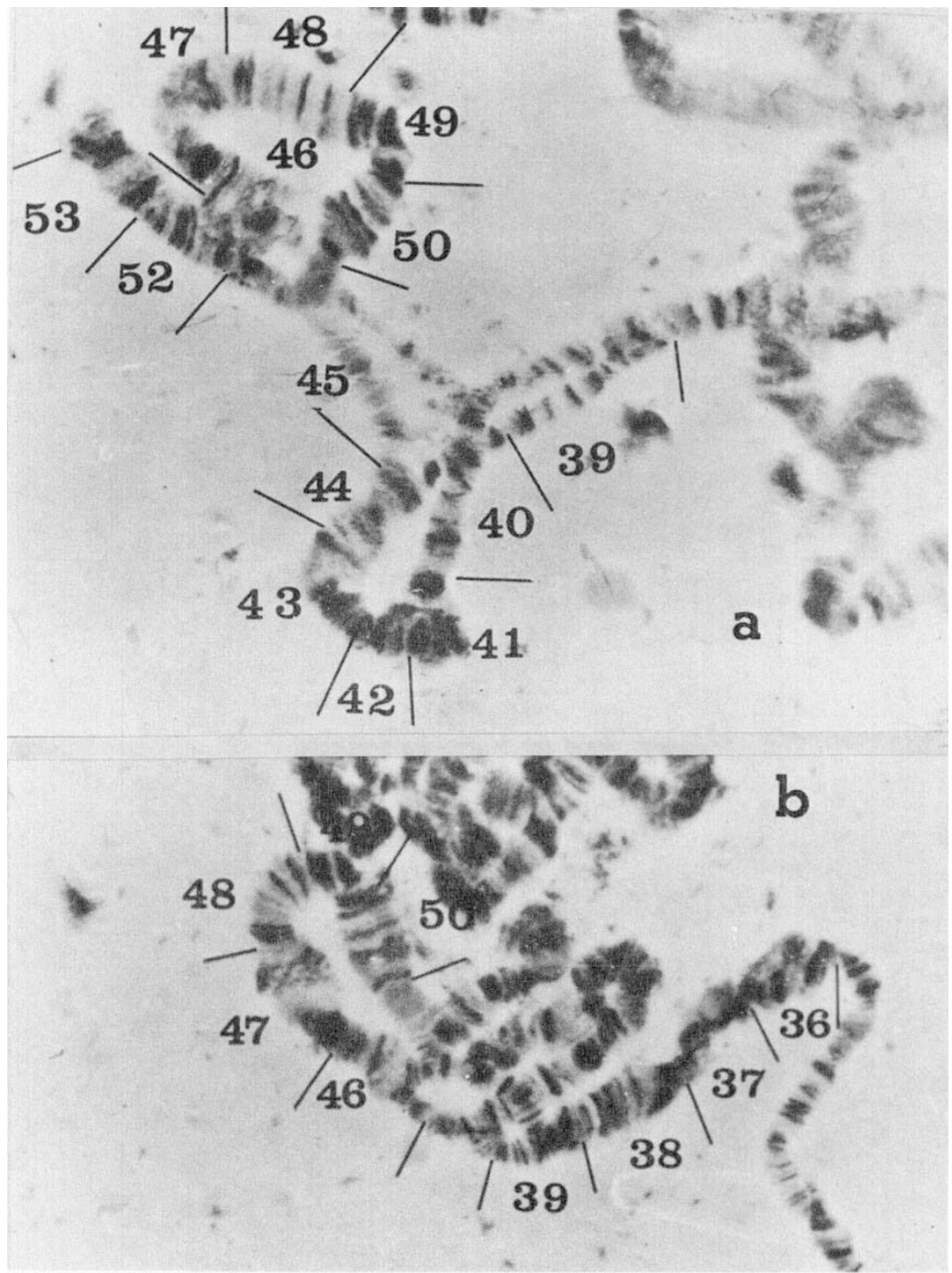

Plate 6. The $U$ chromosomes of $D$. madeirensis $\times D$. subobscura $F_{1}$ hybrids. 


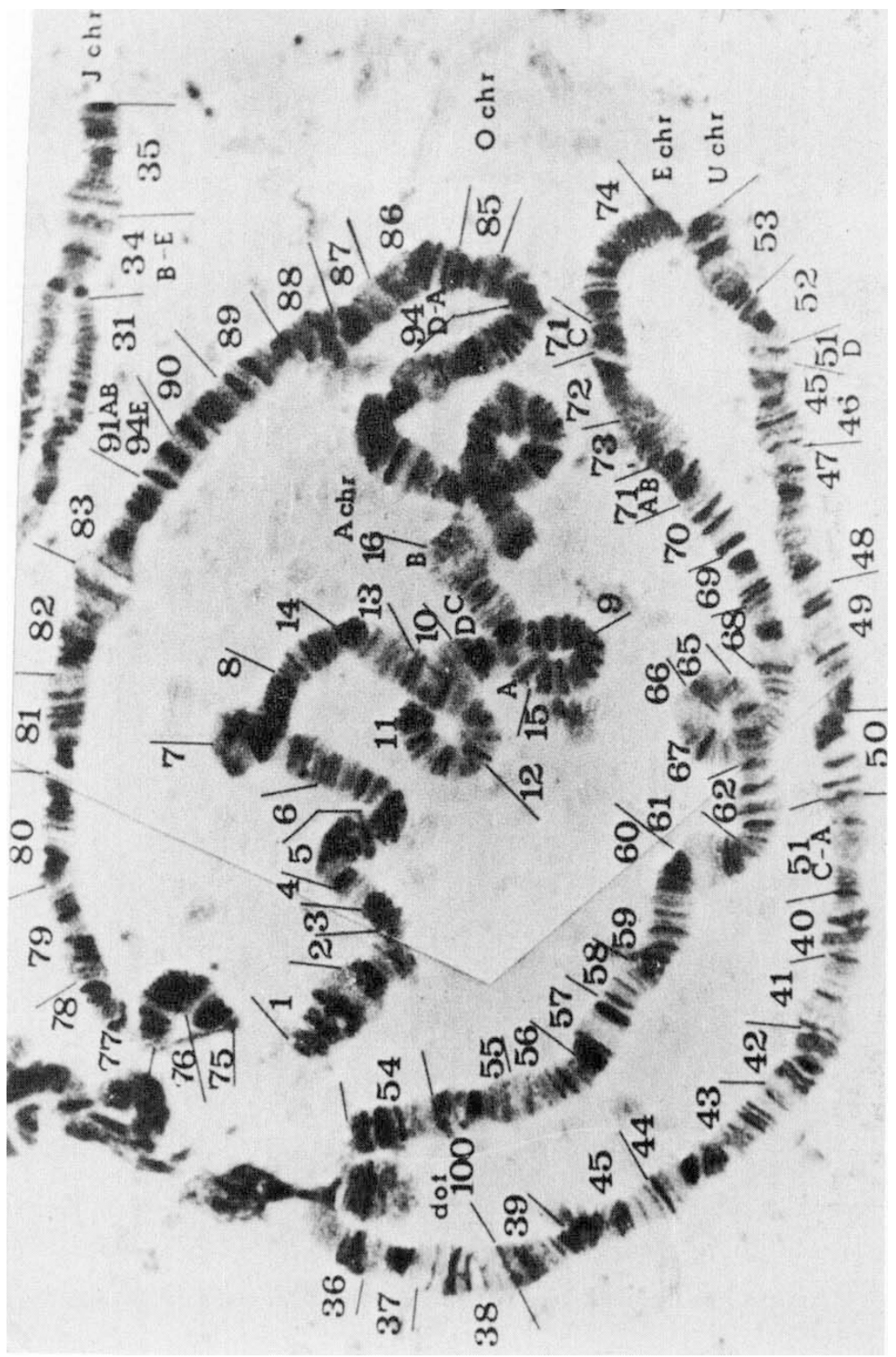

PLATE 7. The salivary chromosome of $D$. guanche. 


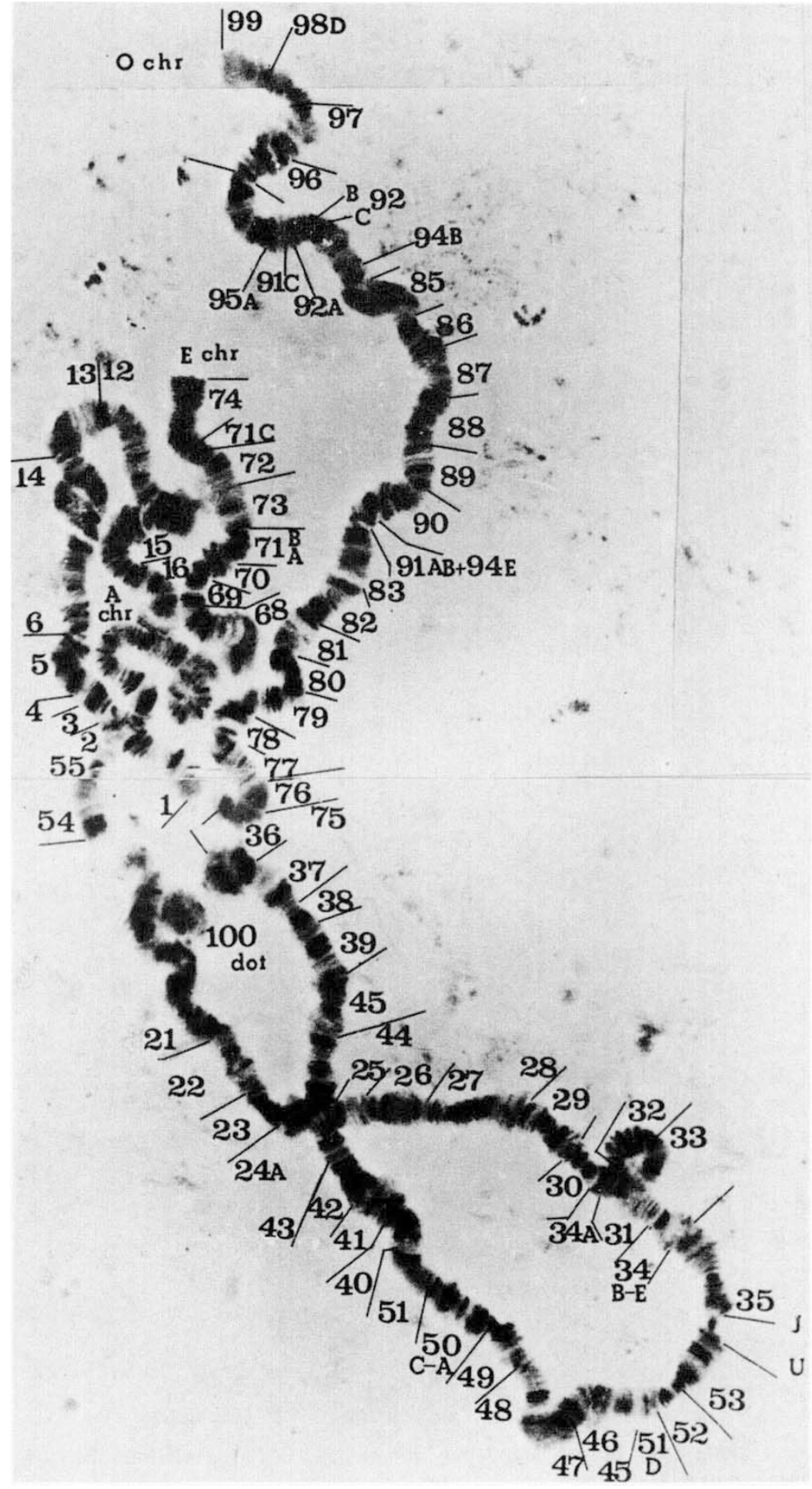

Plate 8. The salivary chromosomes of $D$. guanche. 

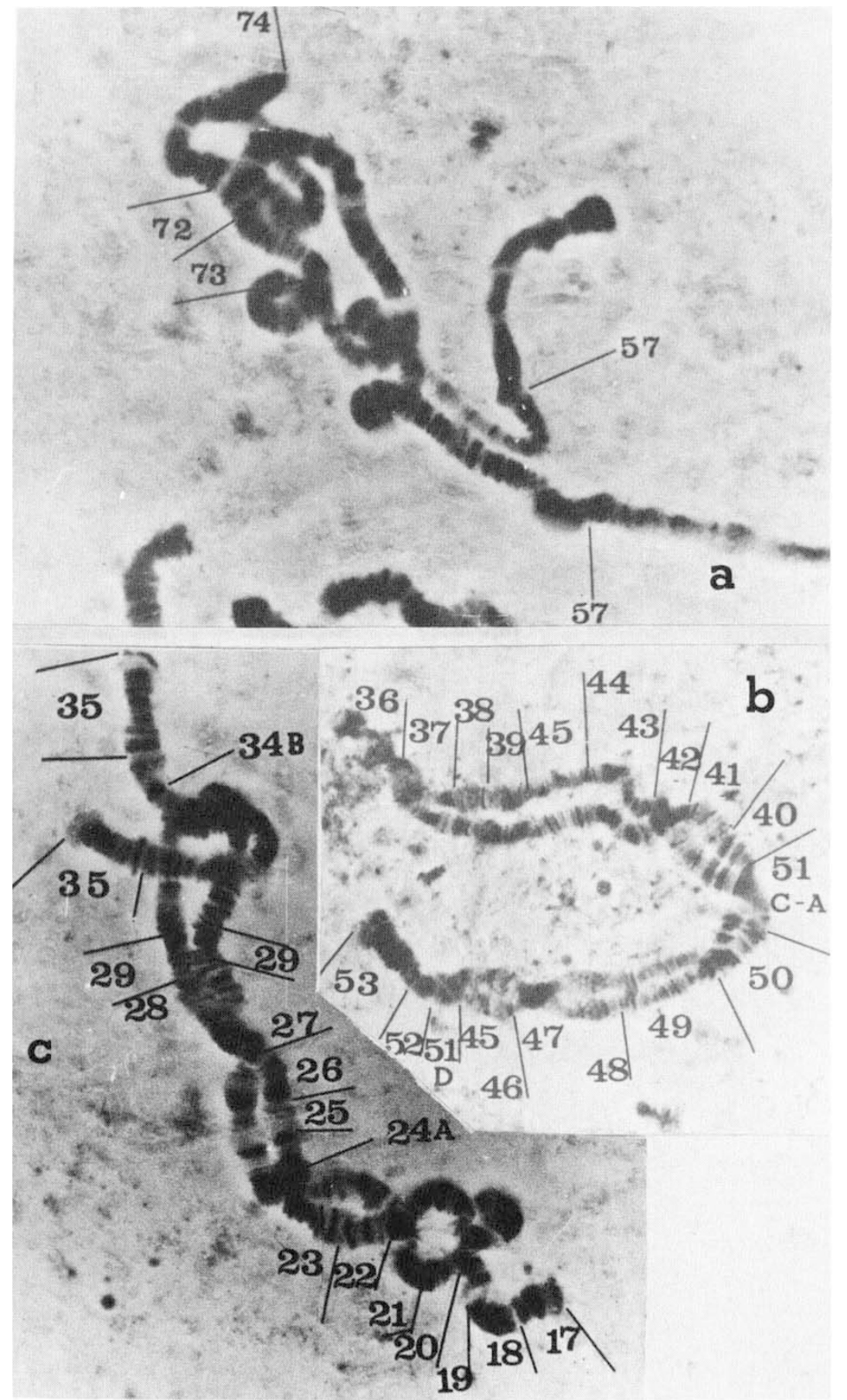

Plate 9. The $E$ (9a), $U(9 \mathrm{~b})$, and $J(9 \mathrm{c})$ chromosomes in $\mathrm{F}_{1}$ hybrids from the cross $D$. madeirensis $\times D$. guanche. 


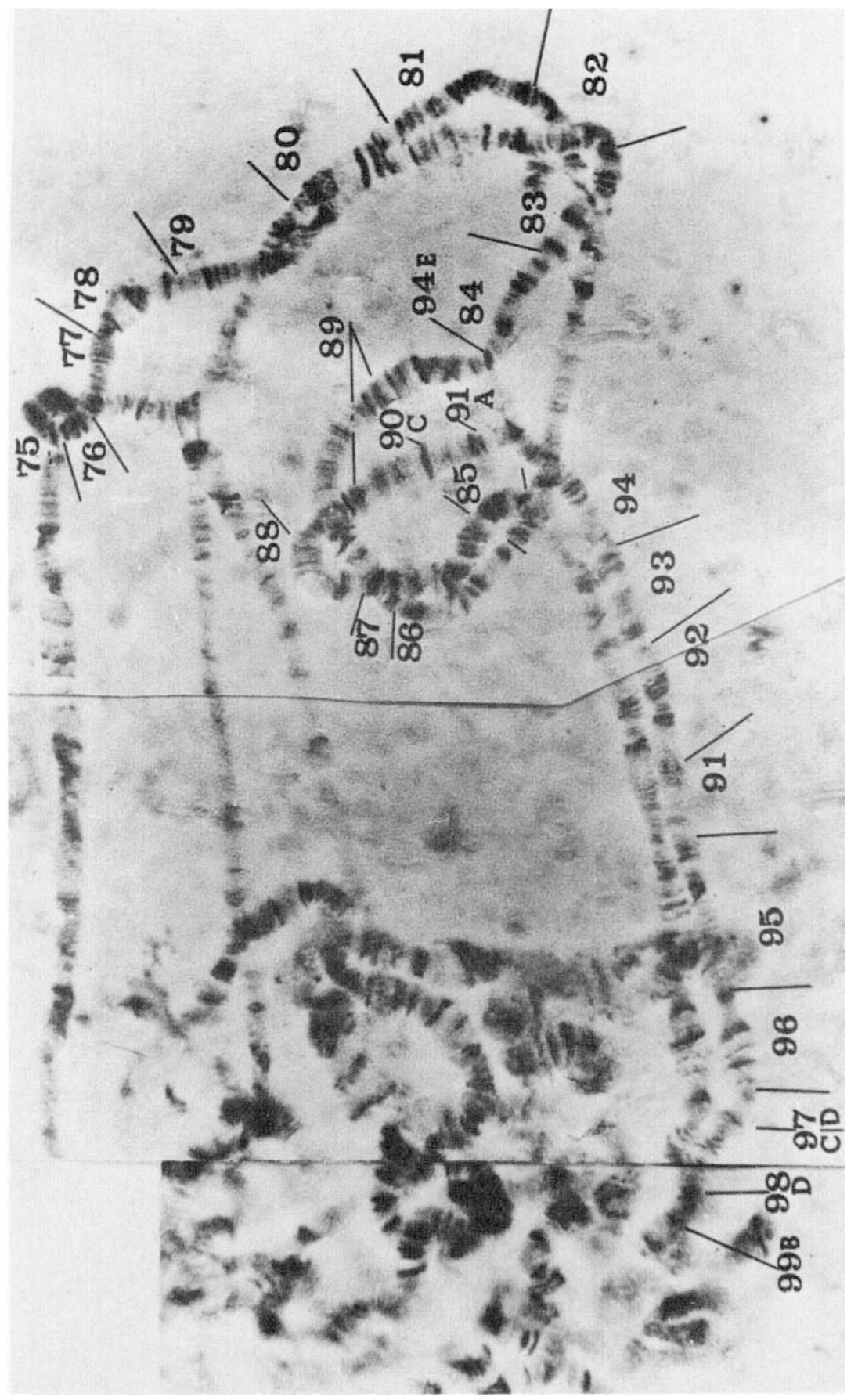

Plate 10. The $O$ chromosome in $D$. madeirensis $\times D$. guanche $F_{1}$ hybrids. 
There is practically no synapsis except for the distal end and the inversion specific to guanche.

Finally in plate 10 we can see the pairing of the $O$ chromosome in madeirensis $\times$ guanche $F_{1}$ hybrids. It is not clear whether section 84 exists in $D$. guanche. However, the inversion specific to $D$. guanche includes $94 E$ until the beginning of 85 . The asynapsis is nearly general but it seems that banding patterns, although somewhat different in details, are very similar.

There is no figure depicting the $\boldsymbol{A}$ chromosome of the hybrids. It seems that natural populations of $D$. guanche do not show inversion heterozygosity (Cabrera, pers. com.). Thus the results obtained with our strain have a general application.

In conclusion, $D$. guanche has the following gene arrangements in comparison to the $S T$ ones of $D$. subobscura: $A($ inv $16 B C D)+($ inv 9-14); $E(\operatorname{inv} 71 A B-73) ; J(\operatorname{inv} 31-34 A) ; O($ inv 3$)+(\operatorname{inv} 85-91 A B+94 E) ; U_{1+2}$.

$D$. guanche has four specific inversions plus two in common with $D$. madeirensis. It differs from this one by having an $A_{S T}$ (instead of $A_{1}$ ) gene arrangement but otherwise is more similar to $D$. madeirensis than to $D$. subobscura.

\section{NOTES ON THE INHERITANCE OF SPECIES SPECIFIC QUANTITATIVE CHARACTERS}

Burla (1951) devised and used several indexes permitting differentiation of the European species belonging to the obscura group known at that time: the ratio of lengths of the first two tarsal segments, the number of teeth in the claspers of the external male genital apparatus, the chaetae on the female ovipositor guide, the number of teeth in the male sex combs as well as four wing indexes, ratios of lengths of different parts of the wing. These eight characters have been measured in the parental species, their $F_{1}$ hybrids and, in the case of $D$. madeirensis $\times D$. subobscura matings, in backcross progeny of the $F_{1}$ with the subobscura male parent. About ten such backcross families were raised and a total number of 88 males and 113 females from this backcross were measured. Not all characters, however, have been measured in all $F_{1}$ and backcrosses.

(i) Ratio of the lengths of the tarsal segments (Ist/IInd)

The mean of the three species under consideration differ and even the individual values nearly do not overlap. Only the $F_{1}$ of the madeirensis $\times$ subobscura cross has been measured: the mean value coincides with that of the subobscura parent, which thus displays complete dominance. No backcrosses were measured (table 1).

\section{(ii) The sum of the number of teeth in both male claspers (forceps)}

The means of madeirensis and subobscura differ but the distributions greatly overlap. The $F_{1}$ mean does not differ from madeirensis $(t=1.02)$ but does so from subobscura. This suggests that the dominant alleles are located in madeirensis. However the $\mathrm{B}_{2}$ mean shows a complete reversion to that of subobscura thus suggesting that the simultaneous presence of more than one factor from madeirensis is needed in order to get an increased number of teeth. This kind of epistatic interaction permits only a few 
TABLE 1

Ratio of the lengths of the two tarsal segments. $n=$ number of individuals measured, $m=$ mean value and $l=$ extreme measurements observed in our sample

\begin{tabular}{ccccc}
\hline & madeirensis & subobscura & guanche & $F_{1}$ (madeirensis $\times$ subobscura) \\
\hline$n$ & 33 & 23 & 19 & 26 \\
$m$ & $1.08 \pm 0.009$ & $1.27 \pm 0.010$ & $1.43 \pm 0.018$ & $1.27 \pm 0.016$ \\
$l$ & $0.97-1.18$ & $1.18-1.34$ & $1.28-1.58$ & $1 \cdot 12-1.38$ \\
\hline
\end{tabular}

TABLE 2

Teeth in male claspers. $v=$ variances, other symbols as in Table 1

\begin{tabular}{ccccc}
\hline & madeirensis & subobscura & $\mathrm{F}_{1}$ (madeirensis $\times$ subobscura) & $\mathrm{B}_{2}\left(\mathrm{~F}_{1} \times\right.$ subobscura $)$ \\
\hline$n$ & 20 & 20 & 22 & 88 \\
$m$ & $13.55 \pm 0.22$ & $12 \cdot 00 \pm 0 \cdot 10$ & $13 \cdot 82 \pm 0 \cdot 14$ & $11.48 \pm 0.09$ \\
$v$ & 0.997 & 0.205 & 0.442 & 0.794 \\
$l$ & $12-15$ & $11-13$ & $13-15$ & $10-15$ \\
\hline
\end{tabular}

TABLE 3

The observed distributions of the number of teeth in male claspers. The numbers indicate the individuals observed

\begin{tabular}{|c|c|c|c|c|c|c|}
\hline & \multicolumn{6}{|c|}{ number of teeth } \\
\hline & 10 & 11 & 12 & 13 & 14 & 15 \\
\hline madeirensis & & & 4 & 4 & 9 & 3 \\
\hline subobscura & & 2 & 16 & 2 & & \\
\hline $\mathrm{F}_{1}$ & & & & 7 & 12 & 3 \\
\hline $\mathrm{B}_{2}$ & 3 & 9 & 58 & 9 & 8 & 1 \\
\hline
\end{tabular}

individuals from the $B_{2}$ to have high teeth number and thus to resemble madeirensis (table 2). Table 3 gives details of the observed distributions. The small variance of the subobscura parent is probably due to the lack of genetic heterogeneity in the strain measured. The $B_{2}$ distribution shows a lack of symmetry due to the 6 individuals (five with 14 teeth and one with 15) which display high teeth numbers. Without them the $B_{2}$ mean could be exactly 12.00 as in the subobscura parent. If these 6 individuals are considered to display the madeirensis phenotype, then the presence of $6.8 \mathrm{per}$ cent of these individuals would suggest the segregation of some 4 independent effective factors (the value expected would be 6.25 per cent). Further investigation is planned to clarify this point, and whether chromosomes can be identified as effective factors.

D. guanche has a mean number of teeth $16.28(7.96$ in one clasper 8.32 in the other) while the 13.55 of madeirensis splits accordingly as 6.59 and 6.95 . Only one $F_{1}$ (madeirensis $\times$ guanche) was measured in one clasper and showed 8 teeth thus resembling the $D$. guanche parent.

(iii) Mean number of chaetae on the female ovipositor guide (vaginal plates)

This is the mean of the left and right parts. Madeirensis has a different mean from the other two, while the distributions of subobscura and guanche 

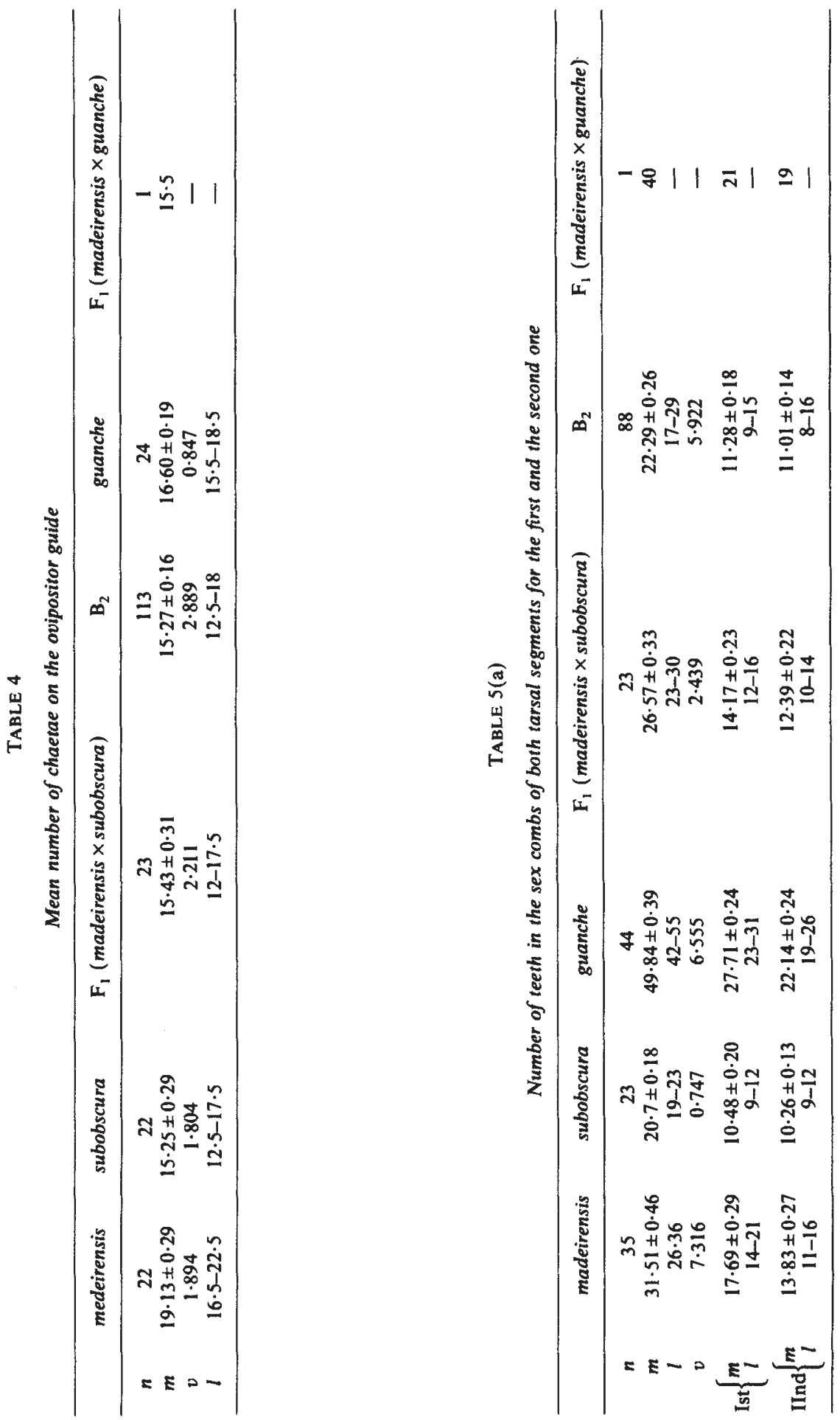
greatly overlap. The $F_{1}$ mean is different from madeirensis but not from subobscura and the $B_{2}$ mean (it is actually the mean of ten families) is similar to $F_{1}$ and to subobscura (table 4 ). The only $F_{1}$ measured between madeirensis and guanche resembles the guanche parent.

(iv) The number of teeth in the sex combs of the first and second tarsal segments added

All three species differ in this number and distributions do not overlap. This is mainly due to the number of teeth on the proximal to the body tarsal segment, the first one (table 5(a)). There is no directional dominance: The $F_{1}$ mean of the madeirensis $\times$ subobscura cross does not differ from the mid parent value $(26 \cdot 125)$, while the $B_{2}$ is slightly greater than the expected without dominance. The other $F_{1}$ (madeirensis $\times$ guanche) seems to follow the same trend, but this is suggested by the measurement of one individual only.

TABLE $5(\mathrm{~b})$

Data derived from those of Table $5 b$ after a scale transformation. Further explanations in the text

\begin{tabular}{ccccc}
\hline & madeirensis & subobscura & $\mathrm{F}_{1}$ (madeirensis $\times$ subobscura) & $\mathrm{B}_{2}\left(\mathrm{~F}_{1} \times\right.$ subobscura $)$ \\
\hline$n$ & 35 & 23 & 23 & 88 \\
$m$ & 1.252 & 0.857 & 1.113 & 0.928 \\
$v$ & 0.0047 & 0.0026 & 0.0029 & 0.0151 \\
\hline
\end{tabular}

Since it seems that in the case of the total number of teeth in the sex combs we have a near additivity we can try to estimate the number of genes using the formula given in Wright $(1968$, p. 394):

$$
n=\frac{\left(\overline{\mathrm{P}}_{2}-\overline{\mathrm{F}}_{1}\right)^{2}}{4\left(\sigma_{\mathrm{B}_{2}}^{2}-\sigma_{\mathrm{E}}^{2}\right)}
$$

where $n$ is the number of genes controlling the character, $\overline{\mathrm{P}}_{2}, \overline{\mathrm{F}}_{1}$ the respective means of $D$. subobscura and the $F_{1}$ hybrid, $\sigma_{B_{2}}^{2}$ the variance of the backcross and $\sigma_{\mathrm{E}}^{2}$ the environmental variance. This last variance could be estimated as the mean of the variances of the $D$. subobscura parent (which is highly homozygous) and of the $F_{1}$. However, it seems that there is an obvious dependence of the environmental variance on the mean. A scale transformation suggested by Wright $(1968$, p. 232$)$ is the following

$$
x^{\prime}=\log (x-13 \cdot 488)
$$

where $x^{\prime}$ are the values of $x$ in the new scale. Table 5(b) provides the estimations of means and variances after scale transformation. The estimation of $\sigma_{\mathrm{E}}^{2}=0.00276$ (the mean of $\sigma_{\mathrm{F}_{1}}^{2}$ and $\sigma_{\mathrm{P}_{2}}^{2}$ ).

Thus

$$
n=\frac{0 \cdot 065}{0.049}=1 \cdot 3 \text {. }
$$

The number of genes involved seems to be between one and two. However this could also mean that no crossing over takes place in $F_{1}$ females (this is apparently the case for chromosome $U$ and partly for $O$ and $A$ at 
least because of inversion heterozygosity) and that the genes controlling the character are located in one or two segregating chromosomes. Further data will clarify whether the actual gene number is so small as one suggested by the punctuated-macromutation theory.

It is interesting to note that our data permit us also to calculate an environmental-intraindividual variance since in 74 cases both the right and the left feet sex combs were measured. This variance turns out to be equal to 0.00253 (the total environmental variance being 0.00276 ). Thus $92 \mathrm{per}$ cent of the total environmental variance is due to intraindividual developmental noise. Nearly the same percentage ( 97 per cent) of total environmental variance was found to be due to an intraindividual variance in the case of abdominal bristle number in Drosophila melanogaster (Reeve and Robertson, 1954).

\section{(v) Wing indexes}

Four wing indexes have been considered: First, the costal index (C.I.) which is the ratio of the length of the second section of the costal vein to that of its third section. Second, the fourth vein index (4v.I) which is the ratio of the lengths of the distal to the median section of the fourth vein. Third, the $4 \mathrm{c}$ index which is the ratio of the third costal section to that of the median section of the fourth vein. Finally, the $5 x$ index which is the ratio of the last section of the fifth vein to that of the posterior cross vein. (table 6). All distributions vastly overlap except perhaps for the $4 \mathrm{c}$ index of madeirensis which differentiates this species from the other two. The $F_{1}$ of madeirensis $\times$ subobscura resembles madeirensis for the costal index (but on the contrary the $F_{1}$ of madeirensis $\times$ guanche shows an absence of dominance), and the same is true for the $4 x$ index (and this in both $F_{1}$ 's), and also for the $4 \mathrm{c}$ index (but the $\mathrm{F}_{1}$ of madeirensis $\times$ guanche displays an absence of dominance). The $5 x$ index differs in this respect: The $F_{1}$ resembles the subobscura parent.

In conclusion, when madeirensis and subobscura are crossed, in one character there is absence of dominance, in three the subobscura parent shows dominance over madeirensis and in the other four, the madeirensis. The $F_{1}$ of madeirensis and guanche shows absence of dominance in three characters, in one the madeirensis phenotype dominates and in two the guanche one.

\section{Discussion}

The three species considered in this paper are apparently closely related and this can also be seen from the examination of their salivary gland chromosomes and those of their $F_{1}$ hybrids. Thus $D$. madeirensis, except for a small inversion in the distal part of the $A$ chromosome, has a constitution that does not differ from known gene arrangements of $D$. subobscura. The case of chromosome $O$ confirms this rule: it is evident that, at some time, inversion $\mathrm{O}_{3}$ was present in this species since the other two arrangements, $O_{S T}$ and $O_{3+4}$, now abundant in its natural populations, necessitated its presence. $D$. guanche, although in many aspects more similar to $D$. madeirensis than to $D$. subobscura, displays an array of inversions specific to this species. The suggested phylogeny from the study of gene arrangements, a first dichotomy giving $D$. guanche, and a later one of the other 


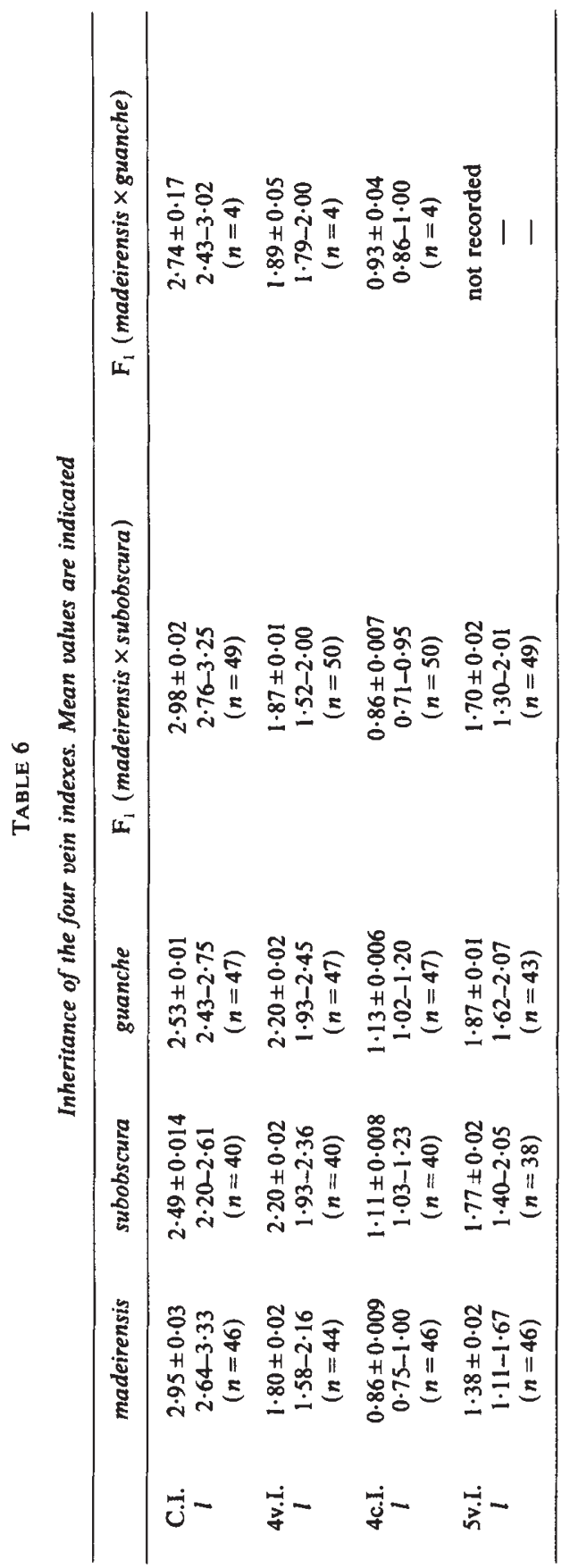


branch $D$. madeirensis and $D$. subobscura, is the same suggested by the morphological differences between these three species as well as the one deduced from the electrophoretic data, as the second paper of this series exemplifies. A word should be added on the antiquity of inversions and especially on the original gene arrangements. Krimbas and Loukas (1980), Pinsker and Sperlich (1981) and other workers during the 1981 second Drosophila subobscura meeting in Barcelona tried to detect the original gene arrangements of this species based mainly on three different criteria: firstly on the centrality of the position in the phylogenetic tree (they actually followed that in Olvera et al. (1979), which is in a sense the usual practice used in converting an unrooted tree to a rooted one e.g., by the UPG method), secondly on the data provided by the actual geographic distribution of gene arrangements (the more widely distributed is infered to be the more ancient), thirdly on the genic polymorphism of genes included within the inversion (the higher the number of effective alleles the more ancient the gene arrangement is). Fig. 1 displays seven gene arrangement phylogenies (chromosomes $A$ and $O$ are considered as composed of two independent segments). By arrows we indicated the middle positions between the most distant arrangements found (every arrangement differs from another by one step: a simple inversion) and encircled are the ones found in $D$. guanche and $D$. madeirensis. In table 7 are summarised the

TABLE 7

Gene arrangements infered as original using different criteria by different authors

\begin{tabular}{|c|c|c|c|c|c|}
\hline Chromosome & $\begin{array}{l}\text { Criterion } \\
\text { of } \\
\text { centrality }\end{array}$ & $\begin{array}{l}\text { Krimbas and } \\
\text { Loukas' (1980) } \\
\text { suggestion }\end{array}$ & $\begin{array}{l}\text { Pinsker and } \\
\text { Sperlich } \\
\text { (1981) } \\
\text { suggestion }\end{array}$ & $\begin{array}{l}\text { Prevosti's } \\
\text { suggestion } \\
\text { (pers. com.) }\end{array}$ & $\begin{array}{c}\text { Gene } \\
\text { arrangements } \\
\text { found in } \\
\text { the two } \\
\text { closely related } \\
\text { species }\end{array}$ \\
\hline $\begin{array}{l}A \text { segment I } \\
A \text { segment II }\end{array}$ & $\begin{array}{l}A_{5} \\
A_{2}\end{array}$ & $\begin{array}{c}\qquad A_{S T} \\
A_{2} \\
\text { (or derivative) }\end{array}$ & - & - & $\begin{array}{c}\boldsymbol{A}_{\mathrm{I}}, \boldsymbol{A}_{\mathrm{ST}} \\
\boldsymbol{A}_{\mathrm{ST}}\end{array}$ \\
\hline $\begin{array}{c}J \\
U \\
E \\
O \text { segment I } \\
O \text { segment II }\end{array}$ & $\begin{array}{c}J_{S T} \text { or } J_{3} \\
U_{1+2} \\
E_{1+2} \\
O_{3} \\
O_{S T}\end{array}$ & $\begin{array}{c}J_{1} \\
U_{1+2} \\
E_{1+2} \\
O_{3+4} \\
O_{S T}\end{array}$ & $\overline{-}$ & $\begin{array}{l}- \\
\overline{O_{s T}} \\
-\end{array}$ & $\begin{array}{c}J_{S T} \\
U_{1+2} \\
E_{S T} \\
O_{3} \\
O_{S T}\end{array}$ \\
\hline
\end{tabular}

original arrangements hypothesised by different authors using different criteria as well as the arrangements found in the two closely related species examined. Krimbas' and Loukas' (1980) predictions depart from the ones that a simple centrality criterion would indicate, in three out of seven instances: a second concomitant criterion is also used by them, that of geographic distribution. Prevosti's prediction is based excusively on the third criterion. If the data provided by $D$. madeirensis and $D$. guanche could be considered to shed some light on this problem it seems that only one out of the five predictions of Krimbas and Loukas (1980) is correct. Indeed the actual geographic distribution is a pattern originating much later and seems to be a poor indicator of antiquity. But centrality also, although 


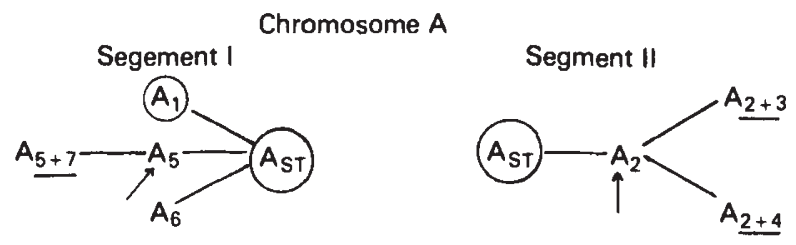

Chromosome J
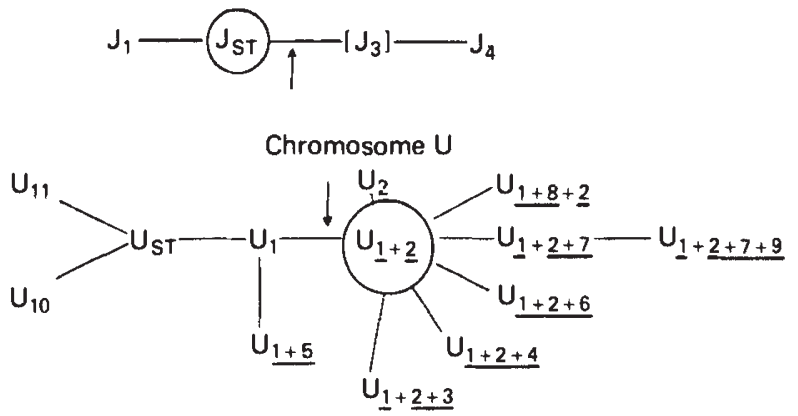

Chromosome E

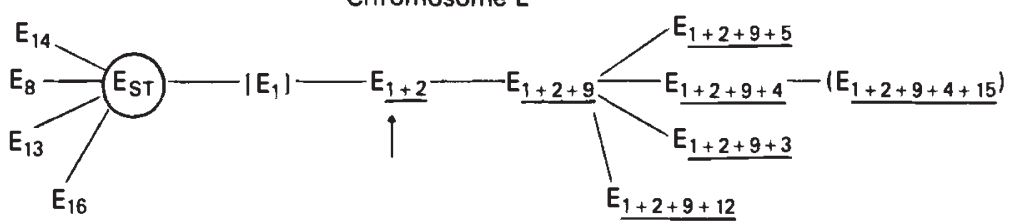

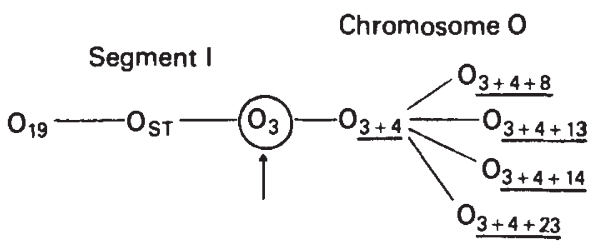

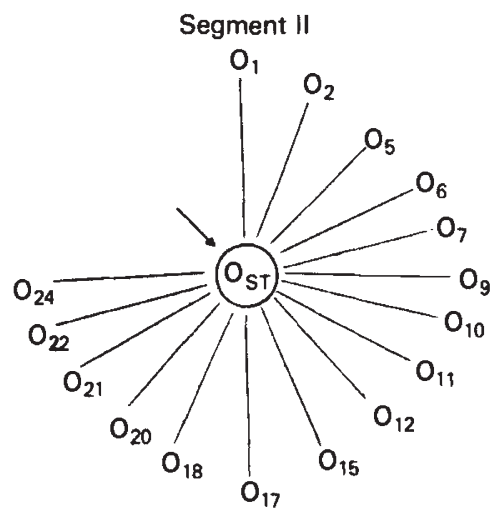

FIG. 1. Unrooted phylogenies for gene arrangements in Drosophila subobscura. They are almost identical to those already published by Krimbas and Loukas (1980), except for inversion $O_{16}$ which is omitted as found identical to $O_{23}$ (Pinsker and Sperlich, 1981) and $E_{16}$ which is added (Sperlich, Pinsker and Mitrophanov, 1981). Further explanations in the text. 
providing better predictions, seems to lead to wrong answers in three out of seven cases! It is a criterion of a rather dubious value. On the other hand the observation that $O_{S T}$ has more genetic heterogeneity than $O_{3+4}$ in the inverted segment can now be clarified when the original arrangement is neither the first or the second but the "then hypothetical" $\mathrm{O}_{3}$. Another hypothesis to suffer from these results is the one advanced by Zapata, Santos and Alvarez (1982) which explains the coexistence of triads, contrary to the Wallace's rule, and predicts at the same time the original arrangements of a triad. Their predictions were nearly identical to those of Krimbas and Loukas (1980), that is to say they considered as original the gene arrangements $U_{1+2}, E_{1+2+9}$ and $O_{3+4}$. From the data presented here, only the first of them could be considered correct.

The case of finding a hypothetical missing link in an inversion phylogeny is interesting per se. First it provides strong evidence in favor of the principles used in order to construct gene arrangement phylogenies (inversions are very rare, unique or historical events in the history of species) and also constitutes a further proof of the evolutionary process in general. This is not, of course, the first case of such a scientific finding, Dobzhansky having already encountered identical situations in $D$. pseudoobscura and D. azteca (Dobzhansky and Sturtevant, 1938; Dobzhansky, 1941).

The differences of genetic constitution of closely related species, and especially on those variants that control quantitative characters, has recently received an increased interest and many of the various mechanisms explaining speciation events could be clarified when relevant data accumulate. We have concentrated our attention on biometrical characters and indexes used to distinguish other palearctic species belonging to the obscura group. The data, however, are still scanty, partly because the material itself does not allow a complete analysis (an $F_{3}$ is impossible). It is, however, hoped that soon more data, based on chromosomal substitutions, will provide more information on this matter.

Acknowledgements. We would like to thank Professor Antonio Prevosti and Dr MonclúsPrevosti for kindly providing us strains of $D$. guanche and $D$. madeirensis and $\mathrm{Dr} B$. Charlesworth who read the manuscript and suggested important ameliorations. Dr Y. Vergini made some of the measurements, Mr J. Sourdis developed the films, Mrs G. Kolia maintained the strains and helped in crosses and $\mathrm{Mr} \mathrm{V}$. Alevizos made the microscopic preparations. The cost of this research was partly defrayed by a grant from the Hellenic National Research Foundation.

\section{REFERENCES}

Burla, H. 1951. Systematic, Verbreitung und Oekologie der Drosophila-Arten der Schweiz. Rev. Suisse Zool., 58, 23-175.

DOBZHANSKY. TH. 1941. Discovery of a predicted gene arrangement in Drosophila azteca. Proc. Nat. Acad. Sci. Washington., 27, 47-50.

DOBZHANSKY, TH. AND STURTEVANT, A. H. 1938. Inversions in the chromosomes of Drosophila pseudoobscura. Genetics, 23, 28-64.

KRIMBAS, C. B. AND LOUKAS, M. 1980. The inversion polymorphism of Drosophila subobscura. Evol. Biol., 12, 163-234.

KUNZE-MÜHL, E. AND MÜLLER, E. 1958. Weitere Untersuchungen über die chromosomale Struktur und natürlichen Strukturtypen von Drosophila subobscura. Chromosoma, 9, 559570.

larruga, J. M., CABrera, v. M., Conzalez, A. M. AND Gullon, A. 1983. Molecular and chromosomal polymorphism in continental and insular populations from the southwestern range of Drosophila subobscura. Genetica, 60, 191-205. 
MONCLuS, M. 1976. Distribution y ecologia de Drosophilidos en Espana. II Especies de Drosophila de las Islas Canarias, con la descripción de una nueva especie. Biol. R. Soc. Espanola Hist. Nat. (Biol.), 74, 197-213.

Olvera, O., POWEll, J. R., DE LA ROSA, M. E., SAlCeda, V. M., GASO, M. I., GUZMAN, J., ANDERSON, W. W. AND LeVINE, L. 1979. Population genetics of Mexican Drosophila. VI. Cytogenetic aspects of the inversion polymorphism in Drosophila pseudoobscura. Evolution, $33,281-395$.

PINSKER, W. AND SPERLICH, D. 1981. Geographic pattern of allozyme and inversion polymorphism on chromosome $\mathrm{O}$ of Drosophila subobscura and its evolutionary origin. Genetica, 57, 51-64.

REEVE, E. C. R. AND ROBERTSON, F. W. 1954. Studies in quantitative inheritance. VI. Sternite chaeta number in Drosophila: a metameric quantitative character. $Z$. indukt. Abstamm.-u. Vererbungslehte, 86, 269-288.

SPERLICH, D., PINSKER, W. AND MITROFANOv, v. G. 1981. Genetic characterization of a natural population of Drosophila subobscura from the northern Caucasus (USSR) in comparison with other population samples. Genetica, 54, 329-334.

WALLACE, B. 1953. Coadaptation and the gene arrangements of Drosophila pseudoobscura: in International Union of Biological Sciences Symposium on Genetics of Population Structure, pp. 67-94, Fusi, Pavia.

WRIGHT, S. 1968. Evolution and the Genetics of Populations. Volume I Genetic and Biometric Foundations. The University of Chicago Press.

ZAPATA, C., SANTOS, M. AND ALVAREZ, G. 1982. Origin of inversions and Wallace's rule of triads. Evolution, 36, 407-409. 